Annales Geophysicae (2003) 21: 655-659 (C) European Geosciences Union 2003

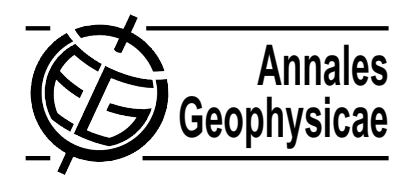

\title{
Regional model simulation of the North Atlantic cyclone "Caroline" and comparisons with satellite data
}

\author{
E. Keup-Thiel ${ }^{1}$, C.-Ph. Klepp ${ }^{1,3}$, E. Raschke ${ }^{1}$, and B. Rockel ${ }^{2}$ \\ ${ }^{1}$ Meteorological Institute, University, Hamburg, Germany \\ ${ }^{2}$ Institute for Coastal Research, GKSS, Geesthacht, Germany \\ ${ }^{3}$ Max-Planck-Institute for Meteorology, Hamburg, Germany
}

Received: 29 October 2001 - Revised: 30 August 2002 - Accepted: 11 September 2002

\begin{abstract}
An individual regional model simulation of cyclone "Caroline" has been carried out to study water cycle components over the North Atlantic Ocean. The uncertainties associated with quantitative estimates of the water cycle components are highlighted by a comparison of the model results with SSM/I (Special Sensor Microwave Imager) satellite data.

The vertically integrated water vapor of the REgional MOdel REMO is in good agreement with the SSM/I satellite data. The simulation results for other water budget components like the vertically integrated liquid water content and precipitation compare also reasonably well within the frontal system. However, the high precipitation rate in the cold air outbreak on the backside of the cold front derived from SSM/I satellite data is generally underestimated by REMO. This results in a considerable deficit of the total precipitation amount accumulated for the cyclone "Caroline". While REMO simulates $24.310^{8} \mathrm{~m}^{3} \mathrm{~h}^{-1}$ for 09:00 UTC, the total areal precipitation from SSM/I satellite data amounts to 54.7 $10^{8} \mathrm{~m}^{3} \mathrm{~h}^{-1}$.
\end{abstract}

Key words. Meteorology and atmospheric dynamics (precipitation; mesoscale meteorology) - Radio science (remote sensing)

\section{Introduction}

The importance of mid-latitude cyclones for climate simulations and weather prediction is well known (Stewart et al., 1998). While the general knowledge of the life cycle of cyclones is sufficiently well developed, details of the energy and water cycle components still needs further attention. General studies on the energy and water cycle of the atmosphere have been initiated by the World Climate Research Program (WCRP) in the frame of GEWEX (Global Energy and Water Cycle Experiment, http://www.gewex.org). In this context regional aspects of the energy and water cycle have

Correspondence to: E. Keup-Thiel (keup@dkrz.de) been investigated over Europe, focussing on the Baltic Sea catchment in the framework of BALTEX (Baltic Sea Experiment, Raschke et al., 1998, 2001). Extra-tropical cyclones play an important role for the water budget over Europe. They are an important source for freshwater. Most of the cyclones reaching Europe develop over the North Atlantic Ocean (Rockel and Karstens, 2001). To better understand these cyclones and their impact on the North Atlantic and European water budget regional model, studies on selected cases have been carried out. The selection of the simulation was guided by the findings during the FASTEX (Fronts and Atlantic Storm Track Experiment, Joly et al., 1997) field campaign. FASTEX has been initiated to improve the forecasts of cyclogenesis and the development of cyclones during January/February 1997. In this program intense ship and aircraft observations took place over the North Atlantic together with drop sonde measurements over the East Coast of North America and Ireland.

Field experiment data sets from FASTEX cannot cover complete cyclones but are valuable for validation. To investigate the water cycle of an individual North Atlantic cyclone in detail, regional model simulations with REMO have been carried out. The amount of the vertically integrated water vapor content, the vertically integrated liquid water content and the precipitation of the cyclone "Caroline", named in the "Berliner Wetterkarte" (Berlin Weather Map) is analysed for 17 February 1997. For verification of model simulations satellite data provide the best spatial and temporal resolution. In the following the results of the REMO simulation and their comparison with SSM/I satellite data are presented and discussed.

\section{The regional model REMO}

REMO is based in its dynamical part on the regional weather forecast model system of the German Weather Service (Majewski, 1991) and on the physical parameterizations of the 


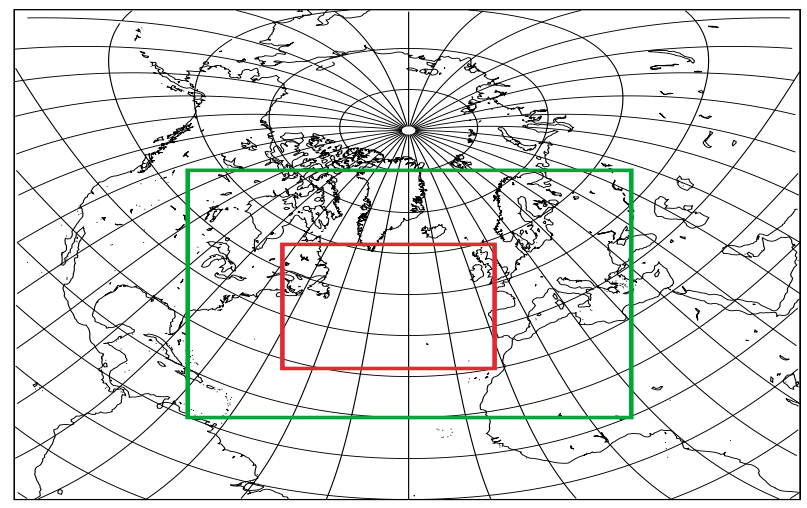

Fig. 1. Model region (small box) and surface data library (large box).

climate model ECHAM4 (European Center dynamics and in HAMburg changed physics, Roeckner et al., 1996).

The physical parameterizations distinguish between stratiform and convective model clouds. The latter are parameterized after Tiedtke (1991) and Nordeng (1994). The mass flux scheme calculates the convective transport of deep, midlevel and shallow convection. Entrainment and detrainment are taken into account. A bulk cloud model calculates cloud liquid water and precipitation. The nonprecipitating cloud liquid water is a source for the liquid water balance of stratiform clouds. The prognostic cloud liquid water content is calculated from the respective budget equation (Sundqvist, 1978), including sources and sinks due to phase changes and precipitation formation by the coalescence of cloud droplets or sedimentation of ice crystals. The distinction between water and ice depends on temperature (Roeckner et al., 1996).

REMO can be driven by climate simulations or analysis data at the lateral boundaries. This allows for the comparison of observations and model results. A detailed description of REMO and several application examples are given in Jacob and Podzun (1997). An application to the water budget analysis over the Baltic Sea catchment has been published by Karstens et al. (1996).

For the presented case study the regional model REMO has been used with a horizontal resolution of 1/6 degrees, corresponding to $241 \times 181$ grid points, 20 vertical levels and a timestep of $60 \mathrm{~s}$. ECMWF-analysis fields in T213 resolution have been used as input at the lateral boundaries and for initialization.

In the current investigation REMO was used in the forecast mode since comparisons with instantaneous satellite data were planned. Each 24-h forecast run started at 00:00 UTC. The first six hours of each run were considered spin up time of the model and, therefore, neglected for the analysis. The model region is outlined by the small box in Fig. 1, which was selected for optimum coverage of the present case study. The large box in Fig. 1 indicates the available area in the library for surface data parameters (Hagemann et al., 1999). The model region can be varied within this area for optimum coverage of additional case studies.

\section{Satellite data}

Remote sensing data of three polar orbiting SSM/I (Special Sensor Microwave/ Imager) radiometers on board satellites of DMSP (Defense Meteorological Satellite Program) are used to derive instantaneous fields of the important water cycle parameters: water vapor content, liquid water content and precipitation rate with a set of algorithms from Bauer and Schlüssel (1993). Their rain rate algorithm is considered to be especially well suited for the determination of mid-latitude convective rain fall through the use of the 85$\mathrm{GHz}$ channel with its spectral sensivity to microwave radiation scattering. This has been outlined in an intercomparison study of various satellite data algorithms with weather data gathered during the FASTEX 1997 campaign on voluntary observation ships. Results of this study show that the Bauer and Schlüssel (1993) rain rate algorithm is sensitive enough to rapidly detect and quantify rainfall patterns in warm and cold fronts, on the cold back sides, as well as in areas of cyclogenesis (Klepp et al., 2003). A complete data coverage over the North Atlantic is obtained twice a day by using a multi-satellite method (Klepp et al., 2000).

The water cycle products derived from SSM/I data for the last twelve years are archived in the HOAPS data base (Hamburg Ocean-Atmosphere Parameters and Fluxes from Satellite Data), which is available at the Max-Planck-Institute for Meteorology in Hamburg (Jost et al., 2002). HOAPS data exhibit a remarkable climatological precipitation maximum around $50^{\circ}$ north and $40^{\circ}$ west. This seems to be related to regularly strong rain events on cold cyclonic backsides, one example of which is treated in the present paper, triggered by the strong sea surface temperature gradient in this region.

\section{Results}

The cyclone "Caroline" covered most of the North Atlantic Ocean on 17 February 1997, as indicated by the pressure contours in Figs. 2-7. The pressure center is located in the southwest of Iceland. "Caroline" is characterized by a raining warm front over Ireland and an intense cold front over the central North Atlantic Ocean. A pronounced convergence zone marks the location of the cold front, characterized by maximum values of the vertically integrated water vapor content (Figs. 2 and 3), the vertically integrated liquid water content (Figs. 4 and 5) and the precipitation rate (Figs. 6 and 7).

The vertically integrated water vapor content of REMO is in good agreement with SSM/I satellite data for the entire region (Figs. 2 and 3). The vertically integrated water vapor content of REMO reaches values of $3 \mathrm{~kg} \mathrm{~m}^{-2}$ at the fronts and is less at the cold backside of the front. The shape of the vertically integrated water vapor content of the SSM/I satellite data is evidently very similar. The results for the vertically integrated liquid water content and the precipitation are reasonable for the cold front. The cold front location and intensity is well simulated by the regional model. The sim- 
REMO
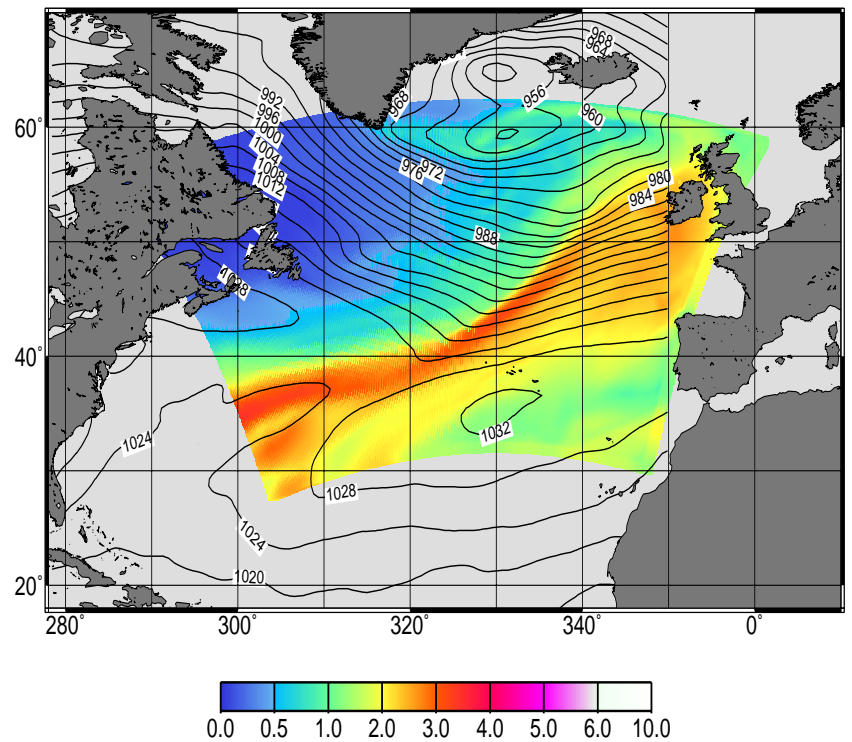

Fig. 2. Vertically integrated water vapor content in $\left(\mathrm{kg} \mathrm{m}^{-2}\right)$ from model simulation for 17 February 1997 at 09:00 UTC.

\section{SSM/I Bauer}

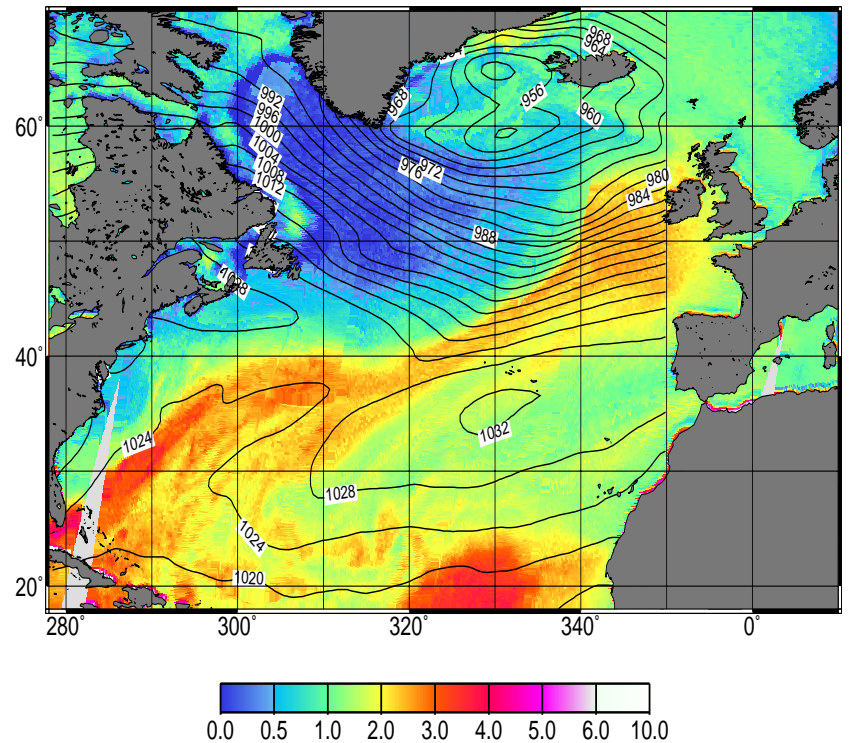

Fig. 3. Vertically integrated water vapor content in $\left(\mathrm{kg} \mathrm{m}^{-2}\right)$ from satellite data for 17 February 1997 at 09:00 UTC.

ulated subsidence zone of REMO just behind the cold front is in good agreement with the satellite data. In the cold front the vertically integrated liquid water content (Fig. 4) reaches maximum values of $1.2 \mathrm{~kg} \mathrm{~m}^{-2}$ in the model simulation, similiar to SSM/I satellite data. Corresponding to this the precipitation rate (Fig. 6) is high at the cold front with values up to $4 \mathrm{~mm} \mathrm{~h}^{-1}$.
REMO

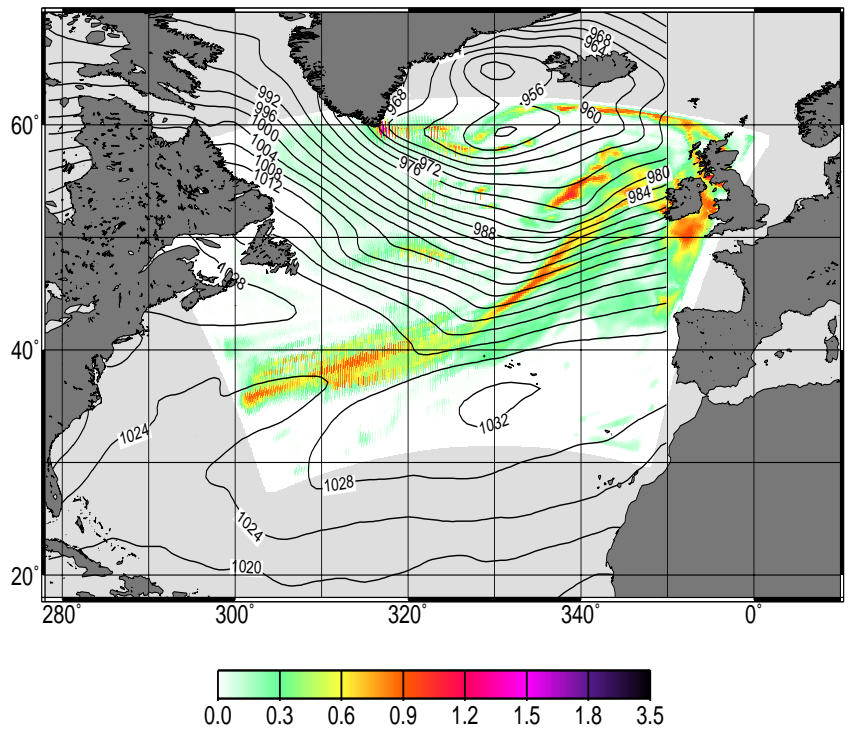

Fig. 4. Vertically integrated liquid water content in $\left(\mathrm{kg} \mathrm{m}^{-2}\right)$ from model simulation for 17 February 1997 at 09:00 UTC.

\section{SSM/l Bauer}

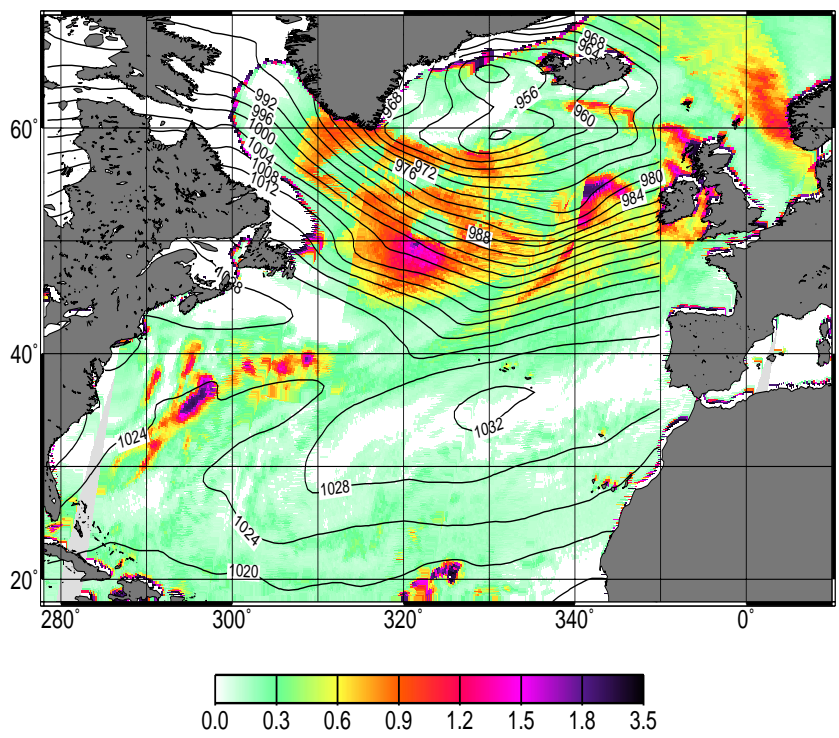

Fig. 5. Vertically integrated liquid water content in $\left(\mathrm{kg} \mathrm{m}^{-2}\right)$ from satellite data for 17 February 1997 at 09:00 UTC.

In contrast to this fairly satisfactory coincidence, neither the vertically integrated liquid water content nor the precipitation rate are in good agreement with the satellite data in the region of the cold air flow behind the cold front. High values of the vertically integrated liquid water content (Fig. 5) and the high precipitation rate (Fig. 7) behind the front exhibited by the satellite data is not shown in the model results (Figs. 4 


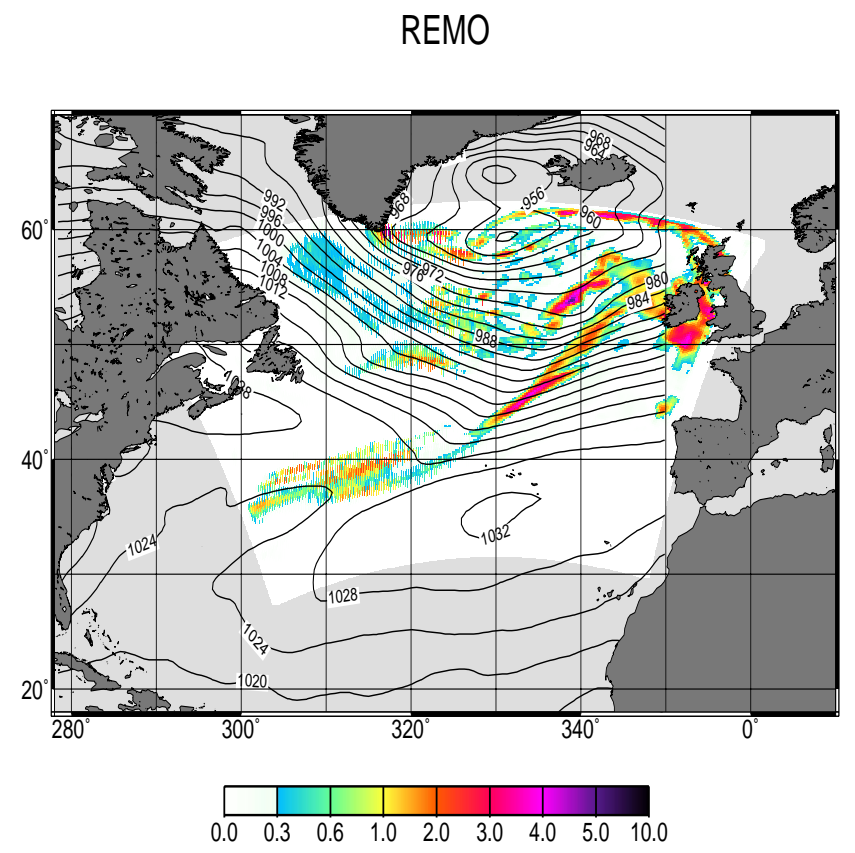

Fig. 6. Precipitation from model simulation in $\left(\mathrm{mm} \mathrm{h}^{-1}\right)$ for 17 February 1997 at 09:00 UTC.

\section{$\mathrm{SSM} / \mathrm{I}$ Bauer}

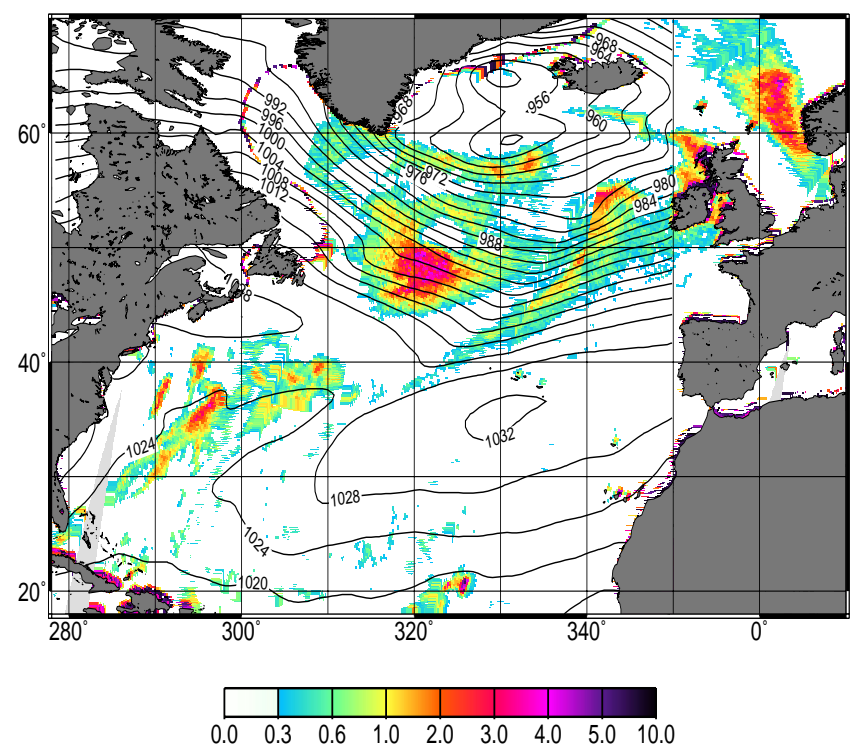

Fig. 7. Precipitation from satellite data in $\left(\mathrm{mm} \mathrm{h}^{-1}\right)$ for 17 February 1997 at 09:00 UTC.

and 6).

The time distribution of the precipitation amount of "Caroline" is shown additionally in Fig. 8. In this figure the precipitation is added over the whole region of the cyclone "Caroline". This is compared to the total precipitation amount derived from SSM/I (Klepp, 2001). REMO simulates 24.3 $10^{8} \mathrm{~m}^{3} \mathrm{~h}^{-1}$ total precipitation at 09:00 UTC. But the total

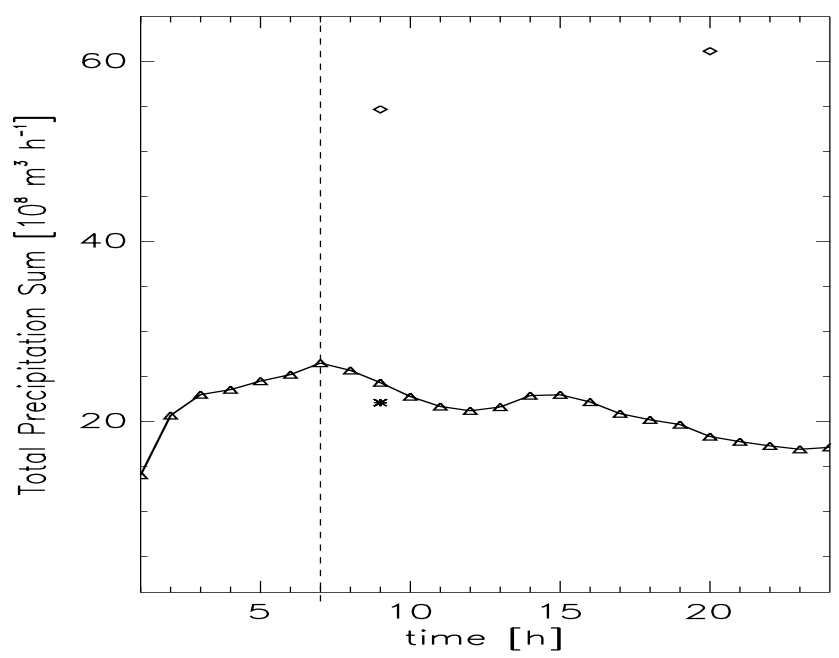

Fig. 8. Total amount of precipitation of the cyclone "Caroline" for 17 February 1997 in $\left(10^{8} \mathrm{~m}^{3} \mathrm{~h}^{-1}\right)$, REMO: triangles connected by a solid line, SSM/I: squares, SSM/I without the backside precipitation: asterisk. The dashed perpendicular line separate the spinup time of the model.

precipitation from the SSM/I satellite data for 09:00 UTC is more than 2 times larger with $54.710^{8} \mathrm{~m}^{3} \mathrm{~h}^{-1}$. If only frontal precipitation is taken into account, neglecting the backside precipitation (depicted by an asterisk in Fig. 8), the value of $22.110^{8} \mathrm{~m}^{3} \mathrm{~h}^{-1}$ represents an acceptable agreement between REMO and SSM/I satellite data (Klepp, 2001).

\section{Conclusions}

The simulation of individual case studies with the regional model REMO yields more detailed information about water cycle components at a higher spatial and temporal resolution than the ECMWF analysis. The precipitation field simulated by REMO shows more detailed structure and higher maximum precipitation rates at the cold front and behind.

The comparison of REMO and SSM/I satellite data is satisfactory for the entire water vapor field, for rain rates at the cold and warm fronts. But the heavy rain event associated with high vertically integrated liquid water content in the cold air outbreak from the Labrador Sea is not simulated. This is an example for high impact weather that should be predicted by the ECMWF model and REMO. The detected model deficit is not only important for forecasts, but also for climate models using the same parameterization scheme. The coupled treatment of atmosphere and ocean requires correct schemes to calculate the fresh water flux.

Possible reasons for this disagreement of precipitation and vertically integrated liquid water content on the backside of the front may be the diagnostic mass flux scheme by Tiedtke (1991), together with the cloud parameterization. The convective mass flux scheme has been developed to simulate deep convection in the tropics and for coarser model resolution. Therefore, the development of new parametariza- 
tion schemes, taking into account higher horizontal or vertical resolutions, needs a new fine tuning. Another way to eliminate this deficiency is to use higher resolutions, so that a parameterization of convection is no longer necessary, because it is explicitly resolved by the model (Keil, 2000). Another possibility for improving forecasts is the assimilation of SSM/I data into model simulations. Since June 1998 the water vapor field is assimilated in the ECMWF analysis and since July 1999 the wind field is assimilated as well. Hence, there is a need for precipiation assimilation in the future.

Further investigations are planned to intensify the comparison with satellite data. The comparison will be extended to further quantities in order to locate in more detail where the reason for this deficiency might come from.

Acknowledgements. This study was funded by the DFG (Deutsche Forschungsgemeinschaft) in the context of the SFB 512 "Cyclones and the North Atlantic Climate System" at the University of Hamburg. The authors thank Dr. Stefan Bakan for his support in editing the final version.

Topical Editor J.-P. Duvel thanks two referees for their help in evaluating this paper.

\section{References}

Bauer, P.: Wasserdampf, Gesamtwasser und Niederschlagsrate aus Daten passiver Mikrowellenradiometer über dem Ozean. Dissertation, Universität Hamburg, DLR Forschungsbericht 123 pp., 1992.

Bauer, P. and Schlüssel, P.: Rainfall, total water, ice water and water vapour over sea from polarized microwave simulations and Special Sensor Microwave / Imager Data, J. Geophys. Res., 98, D11, 20737-20759, 1993.

Hagemann, S., Bozet, M., Dümenil, L., and Machenhauer, B.: Derivation of global GCM boundary conditions from $1 \mathrm{~km}$ land use satellite data, Max-Planck-Institut für Meteorologie, Report No. 289, ISSN 0937-1060, 1999.

Jacob, D. and Podzun, R.: Sensitivity studies with the regional climate model REMO, Meteo. Atmos. Phys., Vienna, Austria, 63, 119-129, 1997.

Joly, A., Jorgensen, D., Shapiro, M. A., Thorpe, A., Bessemoulin, P., Browning, K. A., Cammas, J.-P., Chalon, J.-P., Clough, A. A., Emanuel, K. A., Eymard, L., Gall, R., Hildebrand, P. H., Langland, R. H., Lemaitre, Y., Lynch, P., Moore, J. A., Persson, P. O. G., Snyder, C., and Wakimoto, R. M.: The Fronts and Atlantic Storm-Track Experiment (FASTEX): Scientific objectives and experimental design, Bull. Amer. Meteorol. Soc., 78, 19171940, 1997.

Jost, V., Bakan, S., and Fennig, K.: A new Satellite-derived Freshwater Flux climatology (Hamburg Ocean Atmosphere Parameters and Fluxes from Satellite Data), Meteorol. Z., 11, 61-70, 2002.

Karstens, U., Nolte-Holube, R., and Rockel, B.: Calculation of the water budgets over the Baltic Sea catchment area using the re- gional forecast model REMO for June 1993, Tellus, 48A, 648692, 1996.

Keil, C.: Numerische Simulation von Starkniederschlagsereignissen mit mesoskaligen Wettervorhersagemodellen, DLRForschungsbericht 2000-14, Dissertation, Ludwig-MaximiliansUniversität München, 120 pp., 2000.

Klepp, C. and Bakan, S.: Satellite derived energy and water cycle components in North Atlantic Cyclones, Phys. Chem. Earth (B), 25, 121-128, 2000.

Klepp, C.: Komponenten des Wasserkreislaufs in Zyklonen aus Satellitendaten - Niederschlagsfallstudien -. Dissertation, Universität Hamburg, 161 pp., 2001.

Klepp, C., Bakan, S. and Grassl, H.: Improvements of Satellite Derived Cyclonic Rainfall over The North Atlantic, J. Climate, 16, 657-669, 2003.

Majewski, D.: The Europamodell of the Deutscher Wetterdienst, Seminar Proceedings ECMWF. Vol. 2, 147-191, 1991.

Nordeng, T. E.: Extended Versions of the convective parameterization scheme at ECMWF and their impact on the mean and transient activity of the model in the tropics; ECMWF TechMemo 206, Available from ECMWF, Reading, UK, 1994.

Raschke, E., Karstens, U., Nolte-Holube, R., Brandt, R., Isemer, H.-J., Hoffmann, D., Lobmeyer, M., Rockel, B., and Stuhlmann, R.: The Baltic Sea Experiment BALTEX: A brief overview and some selected results of the authors, Surv. Geophys. 19, 1-22, 1998.

Raschke, E., Meywerk, J., Warrach, K., Andrae, U., Bergström, S., Beyrich, F., Bosveld, F., Bumke, K., Fortelius, C., Graham, L. P., Gryning, S.-E., Halldin, S., Hasse, L., Heikinheimo, M., Isemer, H.-J., Jacob, D., Jauja, I., Karlsson, K.-G., Keevallik, S., Koistinen, J., van Lammeren, A., Lass, U., Launiainen, J., Lehmann, A., Liljebladh, B., Lobmeyr, M., Matthäus, W., Mengelkamp, T., Michelson, D. B., Napiorkowski, J., Omstedt, A., Piechura, J., Rockel, B., Rubel, F., Ruprecht, E., Smedman, A.-S., and Stigebrandt, A.: BALTEX (Baltic Sea Experiment): A European Contribution to Investigate the Energy and Water Cycle over a Large Drainage Basin, Bull. Am. Met. Soc., in press, 2001.

Rockel, B. and Karstens, U.: Development of the water budget for three extra-tropical cyclones with intense rainfall over Europe, Meteorol. Atmos. Phys., 77, 75-83, 2001.

Roeckner, E., Arpe, K., Bengtsson, L., Christoph, M., Claussen, M., Dümenil, L., Esch, M., Giorgetta, M., Schlese, U., and Schulzweida, U.: The atmospheric general circulation model ECHAM4: Model description and simulation of the present day climate, Max-Planck-Institut für Meteorologie, Report No. 218, ISSN 0937-1060, 90 pp., 1996.

Stewart, R. E., Szeto, K. K., Reinking, R. R., Clough, S. A., and Ballard, S. P.: Midlatitude cyclonic cloud systems and their features affecting larger scales and climate, Rev. of Geophysics, 36, 2, 245-273, 1998.

Sundqvist, H.: A parameterization scheme for non-convective condensation including prediction of cloud water content, Quart. J. Roy. Meteor. Soc., 104, 677-690, 1978.

Tiedtke, M.: Aspects of cumulus parameterizations. Seminar proceedings: Tropical and extratropical interactions, 1990, ECMWF, Reading, GB, 1991. 